\title{
Formalin-Fixed Paraffin-Embedded B-Cell (CD20) Digital Image
}

National Cancer Institute

\section{Source}

National Cancer Institute. Formalin-Fixed Paraffin-Embedded B-Cell (CD20) Digital Image. NCI Thesaurus. Code C125612.

A digital image obtained from a formalin-fixed, paraffin embedded CD20-positive B-cell specimen. 